\title{
Spontaneous Expression of the Interleukin 2 Receptor Gene and Presence of Functional Interleukin 2 Receptors on T Lymphocytes in the Blood of Individuals with Active Pulmonary Sarcoidosis
}

Kazuki Konishi, David R. Moller, Cesare Saltini, Martha Kirby, and Ronald G. Crystal
Pulmonary Branch, National Heart, Lung, and Blood Institute, National Institutes of Health, Bethesda, Maryland 20892

\begin{abstract}
Current concepts of the pathogenesis of sarcoidosis suggest that the expanded numbers of activated T-helper/inducer cells at sites of disease activity result, at least in part, from their proliferation in the local milieu. Normal clonal proliferation of $T$ cells involves activation and expression of the IL 2 receptor (IL 2R) gene. Thus, knowing that IL 2R mRNA transcripts are relatively long lived, we hypothesized that sarcoid blood $T$ cells may contain IL 2R mRNA transcripts and express functional surface IL $2 R$, although the cells are probably activated elsewhere. Northern analysis using a ${ }^{32} \mathrm{P}$-labeled $\mathrm{CDNA}$ probe for the IL 2R p55 protein demonstrated that blood $T$ cells of patients with active sarcoidosis, but not of normal patients, express 3.5- and 1.5-kb IL 2R mRNA transcripts, the same as those observed in normal $T$ cells activated in vitro. Consistent with this, using flow cytometry and an MAb directed against the IL 2R p55 protein (2A3), we observed detectable levels of IL 2R surface protein on increased numbers of blood $T$ cells of active sarcoidosis patients $(4.7 \pm 0.9 \%)$ compared with blood $T$ cells of normal patients $(0.9 \pm 0.2 \%)$. Importantly, when the sarcoid blood T cells were exposed to IL 2 in vitro, they proliferated at a rate greater than that of normal blood $T$ cells under the same conditions, suggesting that the IL 2R spontaneously expressed by sarcoid blood $T$ cells were functionally active. In the context of the known compartmentalization of spontaneous IL 2 production and $T$ cell proliferation at sites of disease in active pulmonary sarcoidosis, these IL $2 R$ positive blood $T$ cells would probably have a proliferative advantage if they trafficked to sites of active sarcoidosis, such as the lower respiratory tract.
\end{abstract}

\section{Introduction}

Sarcoidosis is a chronic granulomatous disorder characterized at sites of disease by the accumulation of activated helper/inducer T lymphocytes (1-9). In this context, evaluation of inflammatory cell populations in affected organs of individuals with active sarcoidosis has demonstrated increased numbers of CD4+ (helper/inducer) $\mathrm{T}$ cells that express surface activation markers such as the IL 2 receptor (IL $2 \mathrm{R})^{1}(10,11)$, D-related-

Address reprint requests to Dr. Ronald G. Crystal, Pulmonary Branch, National Heart, Blood, and Lung Institute, Building 10, Room 6D03, National Institutes of Health, Bethesda, MD 20892.

Received for publication 13 August 1987 and in revised form 13 April 1988.

1. Abbreviations used in this paper: FITC, fluorescein isothiocyanate; IL $2 R$, interleukin 2 receptor.

The Journal of Clinical Investigation, Inc.

Volume 82, September 1988, 775-781 antigen $(8,11,12), 5 / 9(13)$, and very late activation antigen-1 (VLA-1) (14). Furthermore, these T cells at the site of disease proliferate at an exaggerated rate and release mediators typical of activated $T$ lymphocytes, including IL 2 (11, 15-17), IFN- $\gamma$ $(18,19)$, monocyte chemotactic factor $(4,13)$, and a nonspecific stimulus for Ig production by $B$ lymphocytes $(13,20)$. In comparison, evaluation of the blood of these individuals demonstrates decreased numbers and proportions of $\mathrm{CD} 4+\mathrm{T}$ cells. Furthermore, the blood $\mathrm{T}$ cells do not proliferate, and do not release the mediators spontaneously released by their autologous counterparts that are compartmentalized at sites of disease $(2-5,8,11,13-16,18,20)$. Consistent with these observations, lung $\mathrm{T}$ cells of these individuals spontaneously express the IL 2 gene, whereas the blood T cells do not (21). Although sarcoidosis is a systemic disorder, in that it often involves several organs, in the context of the observation of the compartmentalization of activated $T$ cells to the sites of disease, it thus has been concluded that the activation of these $T$ lymphocytes occurs locally at the sites of disease and the activated $T$ cells accumulate in the local milieu. Activation thus is not a generalized property of $\mathrm{T}$ cells throughout the bodies of patients with active sarcoidosis $(2-5,8,11,13-16,18,20,21)$.

That $\mathrm{T}$ cells traffic from organs to lymph node to blood and back (22-28), together with recent observations suggesting similar $\mathrm{T}$ cell antigen receptor $\beta$-chain gene rearrangements of $T$ cells in both blood and lung of patients with active sarcoidosis (29), has led us to ask whether blood T cells of such individuals are truly quiescent, or whether a proportion of these cells has been at least partially activated. We thus capitalized on the knowledge that, of the immune response genes expressed after activation, IL $2 \mathrm{R}$ mRNA transcripts are relatively long lived (30-33). These observations led us to hypothesize that $T$ cells in the blood of patients with active sarcoidosis may spontaneously express IL $2 \mathrm{R}$ genes. The data not only support this concept by demonstrating that sarcoid blood T cells contain IL 2R p55 chain mRNA transcripts and express surface IL 2 receptors, but show that these sarcoid $T$ lymphocytes respond to exogenous IL 2 by proliferating in an exaggerated fashion. This suggests that if these $T$ cells migrate to compartments in which IL 2 is released, they are primed to proliferate in the local milieu.

\section{Methods}

Study population. Using previously defined criteria, including lung biopsy, the diagnosis of sarcoidosis was established in 13 individuals (2). No patients were receiving therapy at the time of study or within the previous $2 \mathrm{mo}$. There were 3 males and 10 females; the average age was $33 \pm 2$ yr. (All data are presented as mean \pm SEM; all statistical comparisons were made using the two-tailed $t$ test.) 10 were nonsmokers and 3 were exsmokers for a minimum of 2 yr. All had abnormal chest $\mathrm{x}$ rays (type I $[n=1]$, type II $[n=8]$, and type III [ $n=4]$ ) (34). On 
the average, lung function testing (35) revealed reduced lung volumes (vital capacity $63 \pm 4 \%$ predicted, total lung capacity $63 \pm 4 \%$ predicted), reduced diffusing capacity (58 $\pm 5 \%$ predicted, corrected for volume and hemoglobin), and normal airflow (forced expiratory volume in 1 s/forced vital capacity $108 \pm 1 \%$ predicted). Using previously defined criteria $(2,36)$, we determined that all patients had active sarcoidosis. All had positive gallium-67 scans (37). Bronchoalveolar lavage revealed (38), on the average, $60 \pm 2 \%$ fluid recovered and $89 \pm 8 \times 10^{6}$ cells recovered. The cell differential was typical for active sarcoid, including $54 \pm 6 \%$ lymphocytes, $43 \pm 6 \%$ alveolar macrophages, $2 \pm 1 \%$ neutrophils, and $1 \pm 1 \%$ eosinophils. Evaluation of lymphocyte phenotypes by flow cytometry using a FACS IV (Becton, Dickinson \& Co., Oxnard, CA) with the fluorescein isothiocyanate- (FITC)-conjugated MAbs Leu3 (CD4, helper/inducer T lymphocytes, Becton, Dickinson \& Co.) and Leu2 (CD8, suppressor/cytotoxic T lymphocytes, Becton, Dickinson \& $\mathrm{Co}_{\text {.) }}$ revealed an average CD4+ to CD8+ ratio of $5.0 \pm 1.0$ in the lung and $1.8 \pm 0.2$ in the blood.

For comparison, 28 normal individuals were evaluated. These individuals ( 16 males, 12 females; age $29 \pm 2$ yr, all nonsmokers) had neither history nor evidence of lung disease by physical examination, chest $x$ ray, and pulmonary function tests. None were taking medication at time of the study. Bronchoalveolar lavage revealed $58 \pm 2 \%$ fluid recovered. There were $27 \pm 4 \times 10^{6}$ cells recovered with a cell differential of $89 \pm 3 \%$ alveolar macrophages, $9 \pm 2 \%$ lymphocytes, $1 \pm 1 \%$ neutrophils, and $<1 \%$ eosinophils.

Source of lymphocytes. Blood T lymphocytes were purified from heparinized blood by Ficoll-Hypaque (Litton Bionetics, Inc., Kensington, MD) gradient centrifugation (39) followed by the passage of cells over nylon wool columns (40). Lung $T$ lymphocytes were purified from bronchoalveolar lavage samples by passage over nylon wool columns. The resultant blood and lung $\mathrm{T}$ lymphocyte populations were $>98 \%$ viable (trypan blue exclusion) and $>95 \%$ pure as assessed by flow cytometry with the FITC-conjugated OKT11 MAb (CD2, panT; Ortho Diagnostic Systems, Inc., Johnson \& Johnson, Raritan, NJ).

Evaluation of $T$ lymphocytes for $I L 2 R M R N A$ transcripts. Total cellular RNA was isolated using guanidine isothiocyanate and cesium chloride centrifugation $(41,42)$. 5- $\mu$ g RNA samples were evaluated for the presence of IL $2 R$ mRNA transcripts using Northern analysis (43) and a ${ }^{32} \mathrm{P}$-labeled cDNA probe coding for the IL $2 \mathrm{R}$ p55-chain (specific activity of $2-5 \times 10^{8} \mathrm{dpm} / \mu \mathrm{g}$ ). The IL $2 \mathrm{R}$ cDNA probe (44) was derived from the plasmid pIL2R2, encompassing exons I through VI and the first 20 bp of exon VII of the IL 2R p55-chain cDNA (pIL2R2 was a gift of T. Waldmann, National Cancer Institute). As a control, parallel filters were hybridized with cDNA of the human $\gamma$-actin gene (plasmid PHFrA-1, provided by P. Gunning and L. Kedes, Stanford University [45]). The blood and lung $T$ cells from patients with sarcoid and the blood $\mathrm{T}$ cells from normal patients were evaluated immediately after purification, with no added stimulation. As a control, $T$ cells were cultured in RPMI 1640 medium (Biofluids, Inc., Rockville, MD) supplemented with $10 \%$ FCS (Biofluids, Inc.), $2 \mathrm{mM}$ glutamine, 100 $\mathrm{U} / \mathrm{ml}$ penicillin, and $100 \mu \mathrm{g} / \mathrm{ml}$ streptomycin together with $5 \mu \mathrm{g} / \mathrm{ml}$ PHA (Burroughs-Wellcome, Research Triangle Park, NC) plus 2 ng/ml PMA (phorbol myristate acetate; Sigma Chemical Co., St. Louis, MO) for $6 \mathrm{~h}$ at $37^{\circ} \mathrm{C}$. The relative amounts of IL $2 \mathrm{R}$ mRNA present in total cellular RNA of $\mathrm{T}$ lymphocytes from each individual were determined by densitometric comparisons of the autoradiograms using laser densitometry (2202 Ultrascan; LKB Instruments, Gaithersburg, MD). Results are presented in arbitrary units ranging from 0 to 100 , calculated by a linear plot, with 0 representing background densitometric signal and 100 representing the densitometric signal of a standard pool of RNA obtained from PHA-/PMA-stimulated normal peripheral blood $\mathrm{T}$ cells.

In the context of reports that blood monocytes can express surface IL $2 R$ under certain conditions $(46,47)$ (although significantly fewer per cell than $T$ cells), blood monocytes or lung macrophages contaminating the $T$ cell preparations might contribute to the IL $2 R$ mRNA observed in sarcoid. To exclude this possibility, control experiments evaluated blood monocytes (isolated by adherence for $1 \mathrm{~h}$ at $37^{\circ} \mathrm{C}$ on plastic dishes; $>95 \%$ pure by morphology and nonspecific esterase staining) and alveolar macrophages (isolated by adherence for $1 \mathrm{~h}$ at $37^{\circ} \mathrm{C}$ on plastic dishes, $>99 \%$ pure by morphology and nonspecific esterase staining) from patients with active sarcoidosis for the presence of IL 2R mRNA transcripts.

Evaluation of the expression of $I L 2 R$ on $T$ lymphocytes. The expression of surface IL $2 R$ by blood $T$ cells in sarcoid patients and normals was evaluated by direct immunofluorescence using $2 \mathrm{~A} 3 \mathrm{MAb}$, which is specific for the p55-chain protein (48). Ficoll-Hypaque purified blood mononuclear cells $\left(5 \times 10^{6}\right)$ were aliquoted into round-bottom microtiter wells ( 96 wells/plate; Flow Laboratories, McLean, VA) and incubated for $30 \mathrm{~min}$ at $4^{\circ} \mathrm{C}$ with $50 \mu$ l blocking medium $(0.1$ $\mathrm{mg} / \mathrm{ml}$ human IgG [Sigma Chemical Co.], and $0.1 \mathrm{mg} / \mathrm{ml}$ deoxyribonuclease [Sigma Chemical Co.] in PBS, $\mathrm{pH} 7.4$ [Biofluids]). After being centrifuged, the cells were incubated (for $30 \mathrm{~min}$ at $4^{\circ} \mathrm{C}$ ) with FITCconjugated anti-human IL 2R MAb 2A3 (CD25; Becton, Dickinson \& Co.), or with a control FITC-conjugated IgGl monoclonal mouse myeloma protein (Becton, Dickinson \& Co.) in $50 \mu$ of staining medium ( $1 \%$ BSA [Sigma Chemical Co.] and $0.2 \%$ sodium azide [Sigma Chemical Co.] in PBS): The cells were washed three times with staining medium and fixed in $1 \%$ paraformaldehyde in PBS and stored in the dark at $4^{\circ} \mathrm{C}$ until examined. The proportion of cells reacting with MAb was evaluated by single-color immunofluorescence using the FACS IV flow cytometer.

Evaluation of the capacity of blood lymphocytes to respond to IL 2 . To evaluate the functional significance of the surface IL $2 R$ on the sarcoid blood $T$ cells, purified $T$ cells from blood of patients with active pulmonary sarcoidosis and normal patients were evaluated for their ability to proliferate in vitro in the presence of exogenous IL 2. To accomplish this, the purified $\mathrm{T}$ cells were cultured in round-bottom microtiter wells at a concentration of $5 \times 10^{4}$ cells per well in RPMI 1640 medium supplemented with $10 \%$ FCS, 2 mM glutamine, 100 $\mathrm{U} / \mathrm{ml}$ penicillin, and $100 \mu \mathrm{g} / \mathrm{ml}$ streptomycin with or without IL 2 (recombinant human IL 2, final concentration of $10 \mathrm{U} / \mathrm{ml}$; Cetus Corp., Emeryville, CA). $\left[{ }^{3} \mathrm{H}\right]$ Thymidine $(0.5 \mu \mathrm{Ci} /$ well, $110 \mathrm{Ci} / \mathrm{mM} \mathrm{sp}$ act; Amersham Corp., Arlington Heights, IL) was added at the initiation of the culture. After $4,12,24$, and $48 \mathrm{~h}$ at $37^{\circ} \mathrm{C}$, the cells were harvested and cytocentrifuge preparations were processed for autoradiographic analysis (15). The slides were stained with Wright-Giemsa, and a labeling index was determined as the percentage of labeled lymphocyte nuclei per total number of lymphocyte nuclei by counting 1,000 lymphocytes per slide, and the data were expressed as the percentage of lymphocytes incorporating $\left[{ }^{3} \mathrm{H}\right]$ thymidine in the presence of IL 2 minus the percentage of lymphocytes incorporating $\left[{ }^{3} \mathrm{H}\right]$ thymidine in the absence of IL 2.

\section{Results}

Presence of IL $2 R$ mRNA transcripts in sarcoid blood T lymphocytes. Compared with normal blood T cells, $\mathrm{T}$ lymphocytes recovered from the blood of individuals with sarcoidosis contained mRNA transcripts for the IL 2 receptor (Fig. 1). Whereas fresh blood $T$ cells from normal individuals did not show any IL $2 \mathrm{R}$ mRNA transcripts (lane 1 ), they did contain $\gamma$-actin mRNA transcripts (lane 6). When the same cells were stimulated with PHA + PMA, they expressed the major 3.5and 1.5-kb IL 2R mRNA transcripts (lane 2). Strikingly, evaluation of freshly isolated blood $\mathrm{T}$ cells from individuals with active pulmonary sarcoidosis demonstrated the presence of both major 3.5- and 1.5-kb transcripts (see lanes 3-5 for three examples) similar to that observed in normal $\mathrm{T}$ cells that have been stimulated in vitro. When the same nitrocellulose filters were rehybridized with $\gamma$-actin probes, each lane contained similar amounts of $\gamma$-actin mRNA transcripts (lanes 8-10), as that of the normal control (lane 6) i.e., differences in total 


\section{A IL-2R probe}

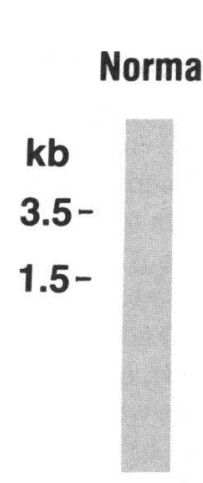

1

\section{Normal}

PHA/PMA

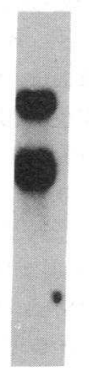

2

B $\boldsymbol{\gamma}$-actin probe

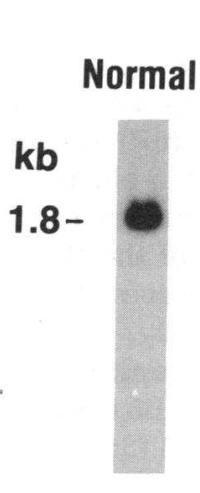

6

\section{Normal} PHA/PMA

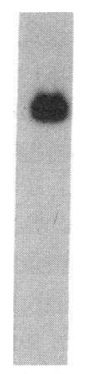

7

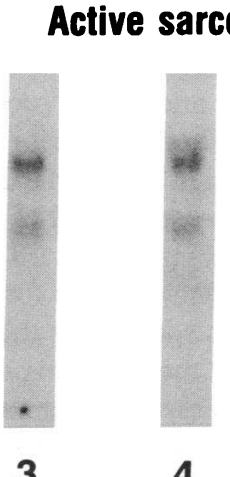

4

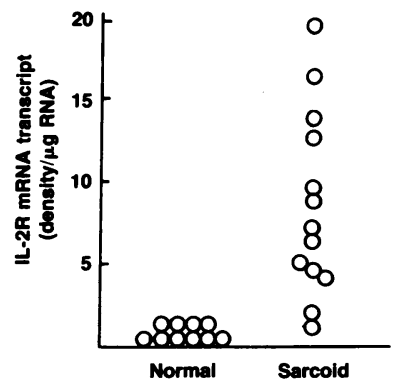

Figure 2. Quantification of IL 2 receptor mRNA transcripts in blood $\mathrm{T}$ lymphocytes in patients with active sarcoidosis and normals. The relative amount of IL 2R mRNA present was determined using densitometry of Northern blots hybridized with a ${ }^{32}$ P-labeled IL 2R cDNA probe similar to that shown in Fig. $1 A$.
When the relative amounts of IL 2R mRNA transcripts in fresh blood $T$ cells from the patients with active pulmonary sarcoidosis were compared with those of normal individuals, it was apparent that the differences observed were consistent throughout the populations evaluated (Fig. 2). Whereas blood $T$ cells of normal individuals had no detectable IL 2R mRNA transcripts, significant amounts of IL $2 R$ mRNA transcripts were seen in all patients with active pulmonary sarcoidosis (8.6 \pm 1.6 density units/ $\mu \mathrm{g}$ RNA). From these observations, it is reasonable to conclude that the IL $2 R$ gene in the T lymphocytes in the blood of individuals with active pulmonary sarcoidosis had recently been activated, resulting in a population of $T$ cells with IL $2 R$ mRNA transcripts.

Consistent with the presence of IL 2R mRNA transcripts in blood T lymphocytes of patients with sarcoid, the same cells expressed surface IL 2 receptors (Fig. 3). In comparison, $<1 \%$ of blood $T$ cells of normal individuals expressed surface IL $2 R$. As a group, patients with active pulmonary sarcoidosis had a markedly higher percentage of IL $2 \mathrm{R}+$ blood $\mathrm{T}$ lymphocytes (sarcoid $4.7 \pm 0.9 \%$ vs. normal $0.9 \pm 0.2 \%, P<0.002$ ).

Like sarcoid blood $T$ cells, evaluation of sarcoid lung $T$ lymphocytes demonstrated detectable surface IL $2 R$ p 55 protein on a significant number of $T$ cells $(5.7 \pm 2.4 \%)$. Consistent with the concept that significant numbers of sarcoid lung $T$ cells have been recently activated to express IL $2 R$ protein, Northern analysis of IL 2R mRNA transcripts in sarcoid lung $T$ cells demonstrated spontaneous expression of both the 3.5and 1.5-kb IL 2R transcripts (not shown). Evaluation of normal lung $T$ cells also demonstrated that a significant number expressed IL 2 R surface protein $(3.1 \pm 5 \%)$, and although the proportion was lower than that seen in sarcoid lung $T$ cells, the difference was not statistically significant $(P>0.05)$. Unfortunately, because there are so few lung $\mathrm{T}$ cells in the normal lung compared with those in sarcoid, despite repeated attempts, we have been unable to purify sufficient numbers of normal lung $\mathrm{T}$ cells to determine if IL $2 \mathrm{R}$ mRNA is spontane-

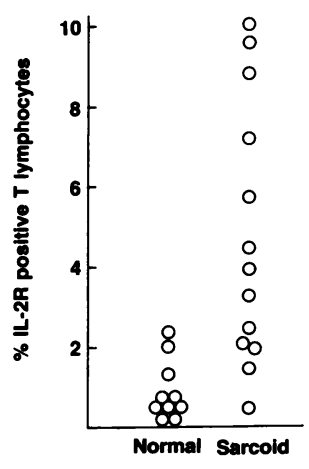

Figure 3. Expression of IL 2 receptors on blood $\mathrm{T}$ lymphocytes of patients with active sarcoidosis and normals. The proportion of IL $2 R$ positive cells was evaluated by single-color immunofluorescence using the MAb 2A3 and FACS analysis. The data are presented as percentage of $T$ cells positively stained with $2 \mathrm{~A} 3$. 
ously expressed in normal lung $\mathrm{T}$ cells. It thus is not possible to state whether the IL $2 R$ surface protein exhibited on the surface of normal lung $T$ cells is matched by similar exaggerated levels of IL $2 R$ mRNA in these cells, as it is in sarcoid lung T cells.

Function of the IL $2 R$ on sarcoid blood $T$ cells. To evaluate the concept that the IL $2 \mathrm{R}$ expressed on the surface of sarcoid blood $\mathrm{T}$ cells were functional (i.e., capable of transmitting the $T$ cell growth-stimulating signal of IL 2), IL 2 was added to sarcoid and normal blood $\mathrm{T}$ cells in vitro and the subsequent rate of $T$ cell proliferation was quantified. Strikingly, the sarcoid $\mathrm{T}$ cells proliferated at a higher rate at all time points observed (Fig. 4; $P<0.001$ sarcoid vs. normal at 4, 12, 24, and $48 \mathrm{~h}$ ). These data are consistent with the concept that the IL $2 \mathrm{R}$ expressed on the sarcoid blood $\mathrm{T}$ cells are functional, conferring upon these cells a proliferative advantage when placed in a milieu with IL 2.

\section{Discussion}

Sarcoidosis is a naturally occurring human model of $\mathrm{T}$ cell activation in which $\mathrm{T}$ cells at sites of disease proliferate at an exaggerated rate and release IL 2 and other lymphokines (2, 3, $11,13,15-21)$. However, whereas $\mathrm{T}$ cells in involved organs show all the features of ongoing activation (8-21), the $T$ cells in blood do not proliferate, express IL 2 mRNA transcripts, or release IL 2 or other lymphokines $(3,11,13,15-21)$. As sarcoid commonly occurs simultaneously in several organs and thus is apparently a systemic disorder, this apparent compartmentalization of $\mathrm{T}$ cell activation has led to the concept that $\mathrm{T}$ cell activation in sarcoidosis is not a generalized feature of $T$ cells (or $T$ cell subsets) throughout the body, but of a class of $T$ cells that accumulate at sites of disease and either remain there or slowly traffic to the blood, but that the blood $\mathrm{T}$ cells are quiescent.

In this study, we have evaluated the expression of IL 2 receptors in blood and lung $\mathrm{T}$ lymphocytes in patients with

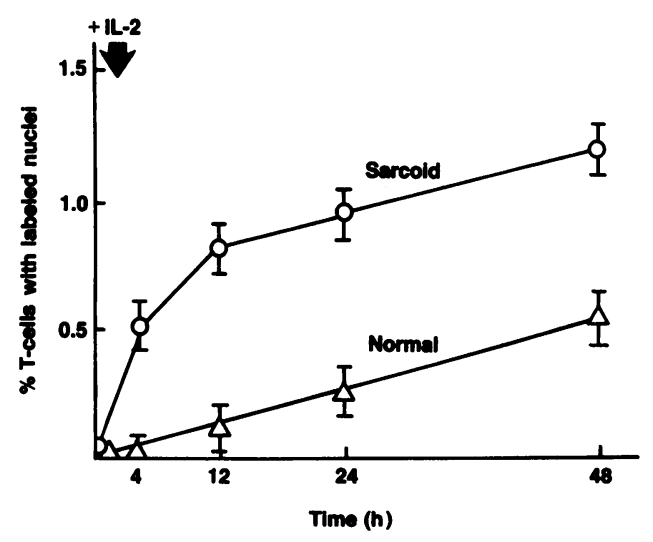

Figure 4. Comparison of the capacity of sarcoid and normal blood T lymphocytes to proliferate in response to IL 2 in vitro. Blood T cells from patients with active pulmonary sarcoidosis $(0)$ and normals $(\Delta)$ were cultured with $\left[{ }^{3} \mathrm{H}\right]$ thymidine with or without $10 \mathrm{U} / \mathrm{ml}$ of recombinant human IL 2. At various time points, cytocentrifuge preparations were analyzed by autoradiography to determine the proportion of labeled $T$ lymphocytes. Individual data points are presented as the percentage of labeled T lymphocytes cultured with IL 2 minus the percentage of labeled T lymphocytes cultured without IL 2. active pulmonary sarcoidosis. The IL 2 receptor is a vital component used in the process of $T$ cell proliferation (50); for $T$ cells to respond to the growth signal IL 2, they must express functional, so-called high affinity IL 2 receptors on their surface (51). It is now recognized that the IL 2 receptor system, originally thought to be composed of one protein (52), is composed of 55- and 70-kD proteins (53). Whereas p55- and p70chains independently form low affinity surface receptors, the functional high affinity IL 2 receptor that responds to IL 2 is thought to be composed of one p55-chain and one p70-chain (54). To evaluate the IL $2 R$ in sarcoid, we have used a cDNA probe (pIL2R2) specific for the IL 2R p55-chain and a MAb (2A3) that is specific for the p55-chain protein (48), and have ensured that the IL $2 R$ expressed by sarcoid $T$ cells were functional by demonstrating that these cells respond to IL 2 by proliferating at a rate greater than that of normal cells.

The finding that sarcoid lung $T$ lymphocytes express IL $2 R$ p55 surface protein and mRNA transcripts concurs with prior evidence of local activation of these cells at a site of disease $(8-21,55)$. However, the evidence in this study of recent IL 2 receptor gene activation in blood $\mathrm{T}$ cells in sarcoid patients suggests that the concept that sarcoid blood $\mathrm{T}$ cells are quiescent should be modified. Three general possibilities explain why sarcoid blood T cells contain IL 2 receptor mRNA transcripts: $(a)$ that the T cells have been activated in blood; $(b)$ that the $T$ cells have been activated in affected organs and have trafficked to blood before the disappearance of the IL 2R mRNA transcripts; or $(c)$ that the IL $2 \mathrm{R}$ gene is permanently activated in a subset of $T$ cells throughout the body.

Consistent with the activation in blood hypothesis, protein that is detected with anti-IL $2 \mathrm{R}$ antibodies 7G7/B6 has been detected in the blood of individuals with sarcoid (56). However, although the likely source of this antigen is shed IL $2 R$ p55-chain (or p55-chain fragments), there is no evidence as to the site of the $\mathrm{T}$ cells from which it was derived.

With respect to the current knowledge of this disorder, the observations in this study are very consistent with the second hypothesis, the local activation-recent trafficking to blood explanation. In this regard, in vitro studies of $T$ cell activation have demonstrated that the IL 2 and IL $2 R$ genes have very different kinetics of expression. Whereas IL 2 mRNA appears early, the mRNA is relatively short lived, so IL 2 mRNA transcripts are markedly diminished $24 \mathrm{~h}$ later (30-33). In comparison, the peak of IL 2R mRNA transcripts, at least for the gene coding for the 55-kD IL 2R p55-chain, is later, with levels peaking at $24 \mathrm{~h}$ and $\mathrm{mRNA}$ transcripts easily detectable at 48 h. In sarcoid, evaluation of IL 2 mRNA transcripts in lung and blood of patients with active pulmonary sarcoidosis has shown that lung, but not blood, T cells contain these gene transcripts (21). Furthermore, when sarcoid lung $T$ cells are placed in culture without stimulation, the IL 2 mRNA transcripts diminished rapidly, similar to what occurs in vitro after $\mathrm{T}$ cell activation $(21,30)$. In the context of in vitro studies of the kinetics of IL 2 and IL 2R mRNA transcripts after in vitro T cell activation, these observations contradict the possibility that $\mathbf{T}$ cells in sarcoid are activated in blood. They support the concept that the $T$ cells have been activated at the sites of disease, but have recently trafficked to the blood. These results concur with known trafficking patterns of lymphocytes activated in response to localized antigens or alloantigens, in which many lymphocytes are initially activated and trapped at the antigen site, but then leave the site of inflammation to 
recirculate throughout the body $(24-26,57,58)$. These migrating cells can selectively emigrate into tissues similar to where the initial stimulation occurred $(57,59)$. In this context, recent studies have identified a class of ubiquinated molecules that allow blood-borne lymphocytes to recognize and bind specialized organ-specific high endothelial venules, thus directing circulating lymphocytes to migrate selectively into different organs and tissues (60-64). Some of the IL $2 R+$ lung $T$ cells in sarcoidosis may represent $T$ cells originally activated in the lung (or elsewhere) that circulate and migrate to the alveolar spaces. However, the presence of both IL 2R mRNA and IL 2 mRNA in sarcoid lung T cells and the fact that no IL 2 mRNA is found in sarcoid blood lymphocytes, argue that at least a proportion of the lung $T$ cells have been activated locally in the lung tissue. Interestingly, normal lung $\mathrm{T}$ lymphocytes express IL $2 \mathrm{R}$ p 55 surface protein, whereas normal blood T lymphocytes express very little $(10,11,52,55,65,66)$. Consistent with these reports, in this study the proportion of IL $2 \mathrm{R}+$ lung lymphocytes approached the proportion of IL $2 \mathrm{R}+$ sarcoid lung lymphocytes. Quantitatively, however, this finding is consistent with the concept that the total number of IL $2 R+T$ cells in the sarcoid lung must greatly exceed that found in the normal lung because of the increased number of total $\mathrm{T}$ cells in the sarcoid lung $(2-16,20,21,36-38,66)$. This difference between sarcoid and normal lung is even more striking when comparing the total number of IL $2 R+T$ cells of the CD4+ $T$ cell subset in the sarcoid versus normal lung $(11,66)$. Furthermore, sarcoid lung T cells produce IL 2 and proliferate at an exaggerated rate, whereas normal lung $T$ cells do not. The stimulus of $T$ cells in the environment of the sarcoid lung thus is both quantitatively and qualitatively different from that found in the normal lung environment. Although these IL $2 R+$ lung $T$ cells in normals might represent $T$ cells, partially activated in the local milieu, that do not traffic to the blood under ordinary conditions, an inability to obtain sufficient numbers of normal lung $\mathrm{T}$ cells for mRNA analysis has made this interpretation speculative. As evidence shows that IL $2 R$ surface protein is present longer than mRNA expression (30, 50,67 ), it is also possible these normal IL $2 R+$ lung $T$ cells are not activated locally, but represent recirculating $T$ cells that have been activated elsewhere and are trapped in the alveolar spaces.

Whereas the evidence in this study directly supports the local activation-recent trafficking to blood hypothesis over the activated in blood hypothesis, the evidence also supports the third hypothesis, that a subset of $T$ cells throughout the body have IL $2 \mathrm{R}$ genes that are chronically activated in a fashion perhaps analogous to that observed in some $T$ cell lines derived from patients with human $T$ cell lymphoblastic virus (HTLV)-1 type lymphoma (68). Furthermore, consistent with this generalized IL $2 \mathrm{R}$ gene activation hypothesis, IL $2 \mathrm{R}$ mRNA transcripts have been detected in lung and blood $T$ cells in sarcoid patients (55). However, although the IL $2 \mathrm{R}$ gene may be generally activated throughout the body, sarcoid does not appear to be associated with HTLV-1 infection (69). Furthermore, when sarcoid blood $\mathrm{T}$ cells are placed in culture over a 24-h period without stimulation, the number of IL $2 R$ mRNA transcripts diminishes, suggesting activation of the IL $2 \mathrm{R}$ gene is not a constitutive property of sarcoid T cells (unpublished observation).

Independent of the mechanism that causes sarcoid blood $T$ cells to contain IL $2 \mathrm{R}$ mRNA and express surface IL 2 recep- tors, the fact that these receptors are functional suggests that circulating sarcoid $\mathrm{T}$ cells have a proliferative advantage compared with normal $T$ cells. In this regard, if these $T$ cells were to traffic to an IL 2-rich environment like that of the sarcoid lung, they may further augment the already ongoing localized exaggerated $\mathrm{T}$ cell proliferative process. Furthermore, since the sarcoid blood $T$ lymphocytes expressing the IL $2 \mathrm{R}$ are those of the helper/inducer $(\mathrm{CD} 4+)$ subclass $(11,66)$, this would likely result in enhanced accumulation of CD4+ T cells at sites of disease, a process that is known to occur in active sarcoidosis $(4,7-9,11-16,21)$.

\section{References}

1. Mitchell, D. N., and J. G. Scadding. 1974. Sarcoidosis. Am. Rev. Respir. Dis. 110:774-802.

2. Crystal, R. G., W. C. Roberts, G. W. Hunninghake, J. E. Gadek, J. D. Fulmer, and B. R. Line. 1981. Pulmonary sarcoidosis: a disease characterized and perpetuated by activated lung T-lymphocytes. Ann. Intern. Med. 94:73-94.

3. Hunninghake, G. W., J. E. Gadek, R. C. Young, O. Kawanami, V. J. Ferrans, and R. G. Crystal. 1980. Maintenance of granuloma formation in pulmonary sarcoidosis by $\mathrm{T}$-lymphocytes within the lung. N. Engl. J. Med. 302:594-598.

4. Hunninghake, G. W., and R. G. Crystal. 1981. Pulmonary sarcoidosis: a disorder mediated by excess helper T-lymphocyte activity at sites of disease activity. N. Engl. J. Med. 305:429-434.

5. Daniele, R. P., J. H. Dauber, and M. D. Rossman. 1980. Immunologic abnormalities in sarcoidosis. Ann. Intern. Med. 92:406-416.

6. Semenzato, G., M. Chilosi, E. Ossi, L. Trentin, G. Pizzolo, A. Cipriani, C. Agostini, R. Zambello, G. Marcer, and G. Gasparotto. 1985. Bronchoalveolar lavage and lung histology: comparative analysis of inflammatory and immunocompetent cells in patients with sarcoidosis and hypersensitivity pneumonitis. Am. Rev. Respir. Dis. 132:400-404.

7. Modlin, R. L., F. M. Hofman, P. R. Meyer, O. P. Sharma, C. R. Taylor, and T. H. Rea. 1983. In situ demonstration of T-lymphocytes subsets in granulomatous inflammation: leprosy, rhinoscleroma and sarcoidosis. Clin. Exp. Immunol. 51:430-438.

8. Costabel, U., K. J. Bross, K. H. Ruhle, G. W. Lohr, and H. Matthys. 1985. Ia-like antigens on T-cells and their subpopulations in pulmonary sarcoidosis and in hypersensitivity pneumonitis. Am. Rev. Respir. Dis. 131:337-342.

9. Paradis, I. L., R. M. Rogers, B. S. Rabin, and J. H. Dauber. 1986. Lymphocyte phenotypes in bronchoalveolar lavage and lung tissue in sarcoidosis. Ann. NY Acad. Sci. 465:148-156.

10. Semenzato, G., C. Agostini, L. Trentin, R. Zambello, M. Chilosi, A. Cipriani, E. Ossi, M. R. Angi, L. Morittu, and G. Pizzolo. 1984. Evidence of cells bearing interleukin-2 receptor at sites of disease activity in sarcoid patients. Clin. Exp. Immunol. 57:331-337.

11. Saltini, C., J. R. Spurzem, J. J. Lee, P. Pinkston, and R. G. Crystal. 1986. Spontaneous release of interleukin 2 by lung $T$ lymphocytes in active pulmonary sarcoidosis is primarily from the Leu3+DR+ T cell subset. J. Clin. Invest. 77:1962-1970.

12. Bauer, W., M. K. Gorney, H. R. Baumann, and A. Morell. 1985. T-lymphocyte subsets and immunoglobulin concentrations in bronchoalveolar lavage of patients with sarcoidosis and high and low intensity alveolitis. Am. Rev. Respir. Dis. 132:1060-1065.

13. Rossi, G. A., O. Sacco, E. Cosulich, A. Risso, B. Balbi, and C. Ravazzoni. 1986. Helper T-lymphocytes in pulmonary sarcoidosis. Functional analysis of a lung $\mathrm{T}$-cell subpopulation in patients with active disease. Am. Rev. Respir. Dis. 132:1086-1090.

14. Saltini, C., M. Hemler, and R. G. Crystal. 1988. Expression of the "very late activation antigen" (VLA-1) complex on lung T-cells characterizes a population of activated nonproliferating T-cells compartmentalized in the normal lung. Clin. Immunol. Immunopathol. 46:221-233. 
15. Pinkston, P., P. B. Bitterman, and R. G. Crystal. 1983. Spontaneous release of interleukin- 2 by lung T-lymphocytes in active pulmonary sarcoidosis. N. Engl. J. Med. 308:793-800.

16. Hunninghake, G. W., G. N. Bedell, D. C. Zavala, M. Monick, and M. Brady. 1983. Role of interleukin-2 release by lung T-cells in active pulmonary sarcoidosis. Am. Rev. Respir. Dis. 128:634-638.

17. Kataria, Y. P., R. C. Padgett, and L. S. English. 1986. Spontaneous production of interleukin-2 in the supernatants of cultured cutaneous sarcoidal granulomas. Ann. NY Acad. Sci. 465:157-163.

18. Robinson, B. W. S., T. L. McLemore, and R. G. Crystal. 1985. Gamma interferon is spontaneously released by alveolar macrophages and lung T-lymphocytes in patients with pulmonary sarcoidosis. $J$. Clin. Invest. 75:1488-1495.

19. Moseley, P. L., C. Hemken, M. Monick, K. Nugent, and G. W. Hunninghake. 1986. Interferon and growth factor activity for human lung fibroblasts. Chest. 89:657-662.

20. Hunninghake, G. W., and R. G. Crystal. 1981. Mechanisms of hypergammaglobulinemia in pulmonary sarcoidosis. Site of increased antibody production and role of $\mathrm{T}$ lymphocytes. J. Clin. Invest. 67:86-92.

21. Muller-Quernheim, J., C. Saltini, P. Sondermeyer, and R. G. Crystal. 1986. Compartmentalized activation of the interleukin 2 gene by lung $\mathrm{T}$ lymphocytes in active pulmonary sarcoidosis. J. Immunol. 137:3475-3483.

22. Jalkanen, S., R. A. Reichert, W. M. Gallatin, R. F. Bargatze, I. L. Weissman, and E. C. Butcher. 1986. Homing receptors and the control of lymphocyte migration. Immunol. Rev. 91:39-60.

23. Navarro, R. F., S. T. Jalkanen, M. Hsu, G. Soenderstrup-Hansen, J. Goronzy, C. Weyand, C. G. Fathman, C. Clayberger, A. M. Krensky, and E. C. Butcher. 1985. Human T cell clones express functional homing receptors required for normal lymphocyte trafficking. $J$. Exp. Med. 162:1075-1080.

24. Lipscomb, M. F., C. R. Lyons, R. M. O'Hara Jr., and J. SteinStreilein. 1982. The antigen-induced selective recruitment of specific $T$ lymphocytes to the lung. J. Immunol. 128:111-115.

25. Klein, J. R., and M. F. Kagnoff. 1984. Nonspecific recruitment of cytotoxic effector cells in the intestinal mucosa of antigen-primed mice. J. Exp. Med. 160:1931-1936.

26. Stein-Streilein, J., P. L. Witte, J. W. Streilein, and J. Guffee. 1985. Local cellular defenses in influenza-infected lungs. Cell. Immunol. 95:234-246.

27. Jalkanen, S., A. C. Steere, R. I. Fox, and E. C. Butcher. 1986. A distinct endothelial cell recognition system that controls lymphocyte traffic into inflamed synovium. Science (Wash. DC). 233:556-558.

28. Freitas, A. A., B. Rocha, and A. A. Coutinho. 1986. Lymphocyte population kinetics in the mouse. Immunol. Rev. 91:5-37.

29. Moller, D., K. Konishi, C. Saltini, J. Spurzem, M. Brantly, B. Balbi, L. Madoo, and R. G. Crystal. 1987. Persistent and similar rearrangements of the T-cell antigen receptor $\beta$-chain gene are present in populations of lung and blood T-cells among individuals with active pulmonary sarcoidosis. Clin. Res. 35:632a. (Abstr.)

30. Leonard, W. J., M. Kronke, N. J. Peffer, J. Depper, and W. C. Greene. 1985. Interleukin 2 receptor gene expression in normal human T lymphocytes. Proc. Natl. Acad. Sci. USA. 82:6281-6285.

31. Kaczmarek, L., B. Calabretta, and R. Baserga. 1985. Expression of cell-cycle-dependent genes in phytohemagglutinin-stimulated human lymphocytes. Proc. Natl. Acad. Sci. USA. 82:5375-5379.

32. Reed, J. C., J. D. Alpers, P. C. Nowell, and R. G. Hoover. 1986. Sequential expression of protooncogenes during lectin-stimulated mitogenesis of normal human lymphocytes. Proc. Natl. Acad. Sci. USA. 83:3982-3986.

33. Granelli-Piperno, A., L. Andrus, and R. M. Steinman. 1986 Lymphokine and nonlymphokine mRNA levels in stimulated human $\mathrm{T}$ cells. Kinetics, mitogen requirements, and effects of cyclosporin A J. Exp. Med. 163:922-937.

34. McLoud, T. C., G. R. Epler, E. A. Gaensler, G. W. Burke, and C. B. Carrington. 1982. A radiographic classification for sarcoidosis. Physiologic correlation. Invest. Radiol. 17:129-138.
35. Fulmer, J. D., W. C. Roberts, E. R. von Gal, and R. G. Crystal. 1977. Small airways in idiopathic pulmonary fibrosis. J. Clin. Invest. 60:595-610.

36. Keogh, B. A., G. W. Hunninghake, B. R. Line, and R. G. Crystal. 1983. The alveolitis of pulmonary sarcoidosis. Evaluation of natural history and alveolitis-dependent changes in lung function. $\mathrm{Am}$. Rev. Respir. Dis. 128:256-265.

37. Line, B. R., G. W. Hunninghake, B. A. Keogh, A. E. Jones, G. S. Johnston, and R. G. Crystal. 1981. Gallium-67 scanning to stage the alveolitis of sarcoidosis: correlation with clinical studies, pulmonary function studies, and bronchoalveolar lavage. Am. Rev. Respir. Dis. 123:440-446.

38. Saltini, C., A. J. Hance, V. J. Ferrans, F. Basset, P. B. Bitterman, and R. G. Crystal. 1984. Accurate quantification of cells recovered by bronchoalveolar lavage. Am. Rev. Respir. Dis. 130:650-658.

39. Boyum, A. 1968. Isolation of mononuclear cells and granulocytes from human blood. Scand. J. Clin. Invest. 21(Suppl. 97):77-89.

40. Henry, C. 1980. Nylon wool. In Selected Methods in Cellular Immunology. B. B. Mishel and S. M. Shigi, editors. W. H. Freeman \& Co., Publishers, New York. 182-185.

41. Chirgwin, J. M., A. E. Przybyla, R. J. MacDonald, and W. J. Rutter. 1979. Isolation of biologically active ribonucleic acid from sources enriched in ribonuclease. Biochemistry. 18:5294-5300.

42. Glisin, V., R. Crkvenjakov, and C. Byrus. 1984. Ribonucleic acid isolated by cesium chloride centrifugation. Biochemistry. 13:2633-2637.

43. Thomas, P. S. 1980. Hybridization of denatured RNA and small DNA fragments transferred to nitrocellulose. Proc. Natl. Acad. Sci. USA. 77:5201-5205.

44. Leonard, W. J., J. M. Depper, G. R. Crabtree, S. Rudikoff, J. Pumphrey, R. J. Robb, M. Kronke, P. B. Svetlik, N. J. Peffer, T. A Waldmann, and W. C. Greene. 1984. Molecular cloning and expression of cDNAs for the human interleukin-2 receptor. Nature (Lond.). 311:626-630.

45. Gunning, P., P. Ponte, H. Okayama, J. Engel, H. Blau, and L. Kedes. 1983. Isolation and characterization of full-length cDNA clones for human $\alpha$-, $\beta$ - and $\gamma$-actin mRNAs: skeletal but no cytoplasmic actins have an amino-terminal cysteine that is subsequently removed. Mol. Cell. Biol. 3:787-795.

46. Herrman, F., S. A. Cannistra, H. Levine, and J. D. Griffin. 1985. Expression of interleukin 2 receptors and binding of interleukin 2 by gamma interferon-induced human leukemic and normal monocytic cells. J. Exp. Med. 162:1111-1116.

47. Mizel, D., D. Hunt, L. Wahl, and S. Wahl. 1987. Inducible gene expression for IL-2 receptors on human peripheral blood monocytes. Fed. Proc. 46:1388a. (Abstr.)

48. Urdal, D. L., C. J. March, S. Gillis, A. Larsen, and S. K. Dower. 1984. Purification and chemical characterization of the receptor for interleukin 2 from activated human T lymphocytes and from a human T-cell lymphoma cell line. Proc. Natl. Acad. Sci. USA. 81:6481-6485.

49. Muraguchi, A., J. H. Kehrl, D. L. Longo, D. J. Volkman, K. A. Smith, and A. S. Fauci. 1985. Interleukin 2 receptors on human B cells. Implications for the role of interleukin 2 in human B cell function. J. Exp. Med. 161:181-187.

50. Cantrell, D. A., and K. A. Smith. 1983. Transient expression of interleukin 2 receptors. J. Exp. Med. 158:1895-1911.

51. Robb, R. J., W. C. Greene, and C. M. Rusk. 1984. Low and high affinity cellular receptors for interleukin 2 . Implications for the level of Tac antigen. J. Exp. Med. 160:1126-1146.

52. Uchiyama, T., S. Broder, and T. A. Waldmann. 1981. A monoclonal antibody (anti-Tac) reactive with activated and functionally mature human T cells. I. Production of anti-Tac monoclonal antibody and distribution of Tac(+) cells. J. Immunol. 126:1398-1403.

53. Sharon, M., R. D. Klausner, B. R. Cullen, R. Chizzonite, and W. J. Leonard. 1986. Novel interleukin-2 receptor subunit detected by cross-linking under high-affinity conditions. Science (Wash. DC). 234:859-863.

54. Teshigawara, K., H. M. Wang, K. Kato, and K. A. Smith. 1987. 
Interleukin 2 high-affinity receptor expression requires two distinct binding proteins. J. Exp. Med. 165:223-238.

55. Konishi, K., C. Saltini, D. Moller, J. Spurzem, and R. G. Crystal. 1987. Expression of IL-2 receptor mRNA and cell surface protein in T-lymphocytes in sarcoidosis. Am. Rev. Respir. Dis. 135:28a. (Abstr.)

56. Lawrence, B. C., K. P. Brousseau, C. C. Kurman, and D. L. Nelson. 1987. Soluble interleukin-2 receptors are present in serum and bronchoalveolar lavage fluids in active sarcoidosis. Sarcoidosis. 4:87-93.

57. Guy-Grand, D., C. Griselli, and P. Vassalli. 1978. The mouse gut T-lymphocyte, a novel type of T-cell. Nature, origin, and traffic in mice in normal and graft-versus-host conditions. J. Exp. Med. 148:1661-1667.

58. Sprent, J. 1980. Antigen-induced selective sequestration of T lymphocytes: role of the major histocompatibility complex. Monogr. Allergy. 16:233-244.

59. Chin, W., and J. B. Hay. 1980. A comparison of lymphocyte migration through interstitial lymph nodes, subcutaneous lymph nodes, and chronic inflammatory sites of sheep. Gastroenterology. 79:1231-1242.

60. Gowans, J. L., and E. J. Knight. 1964. The route of recirculation of lymphocytes in the rat. Proc. R. Soc. Lond. B. Biol. Sci. 159:257-271.

61. Butcher, E. C., R. G. Scollay, and I. L. Weissman. 1980. Organ specificity of lymphocyte migration: mediation by highly selective lymphocyte interaction with organ-specific determinants on high endothelial venules. Eur. J. Immunol. 10:556-561.

62. Gallatin, W. M., I. L. Weissman, and E. C. Butcher. 1983. A cell surface molecule involved in organ-specific homing of lymphocytes. Nature (Lond.). 303:30-34.

63. Siegelman, M., M. W. Bond, W. M. Gallatin, T. St. John, H. T. Smith, V. A. Fried, and I. L. Weissman. 1986. Cell surface molecule associated with lymphocyte homing is a ubiquitinated branched-chain glycoprotein. Science (Wash. DC). 231:823-829.

64. St. John, T., W. M. Gallatin, M. Siegelman, H. T. Smith, V. A. Fried, and I. L. Weissman. 1986. Expression cloning of a lymphocyte homing receptor cDNA: ubiquitin is the reactive species. Science (Wash. DC). 231:845-850.

65. Davidson, B. L., J. Faust, S. Pessano, R. P. Daniele, and G. Rovera. 1985. Differentiation and activation phenotypes of lung $T$ lymphocytes differ from those of circulating $\mathrm{T}$ lymphocytes. J. Clin. Invest. 76:60-65.

66. Saltini, C., J. R. Spurzem, M. R. Kirby, and R. G. Crystal. 1988. Sarcoidosis is not associated with a generalized defect in T-cell suppressor function. J. Immunol. 140:1854-1860.

67. Hemler, M. E., M. B. Brenner, J. M. McLeau, and J. L. Strominger. 1984. Antigenic stimulation regulates the level of expression of interleukin-2 receptor on human T-cells. Proc. Natl. Acad. Sci. USA. 81:2172-2175.

68. Depper, J. M., W. J. Leonard, M. Kronke, T. A. Waldmann, and W. C. Greene. 1984. Augmented T cell growth factor receptor expression in HTLV-1-infected human leukemic T cells. J. Immunol. 133:1691-1695.

69. Pinkston, P., P. Sarin, W. C. Saxinger, B. Hahn, R. Gallo, and R. G. Crystal. 1984. Evaluation of the human T-cell leukemia-lymphoma virus as a possible etiology of sarcoidosis. Am. Rev. Respir. Dis. 129:21a. (Abstr.) 